\title{
Establishing a Global Quarantine Against Weapons of Mass Destruction
}

\section{CONTENTS}

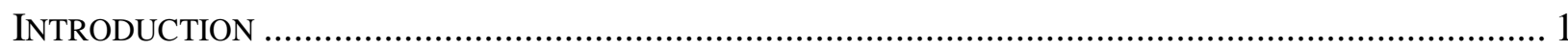

I. EXISTING FrAmEWORKS TO COMBAT WMD PROLIFERATION ............................................. 4

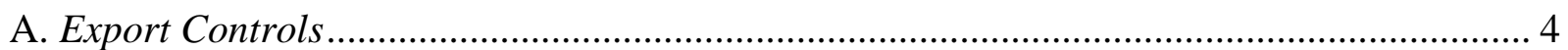

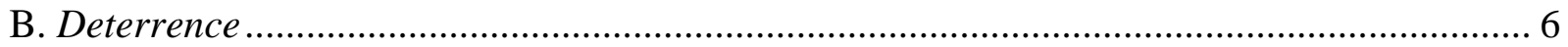

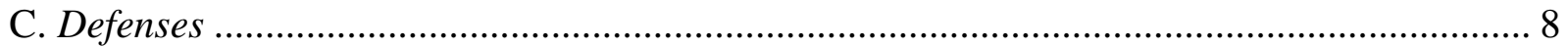

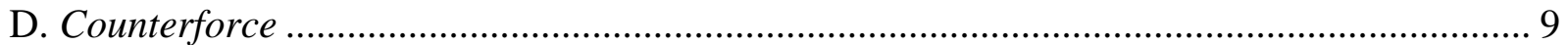

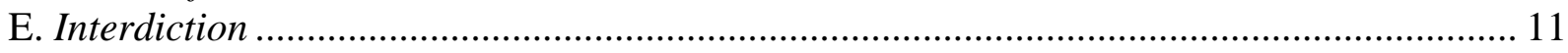

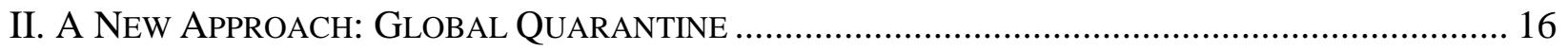

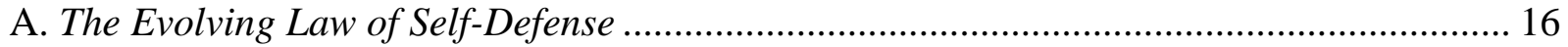

B. Building Blocks of a Global Quarantine ....................................................................... 26

1. International Maritime Organization ....................................................................... 26

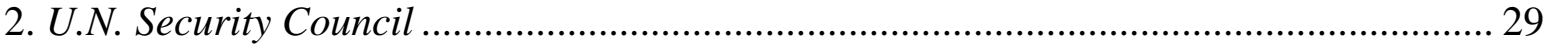

3. Proliferation Security Initiative ........................................................................ 32

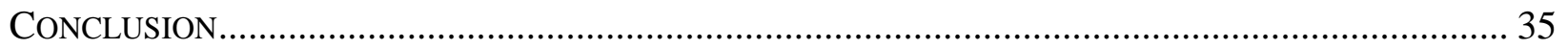

\section{INTRODUCTION}

Faced with mounting international insecurity, in 1937 Franklin Delano Roosevelt gave his famous "Quarantine Speech," likening the rise of fascism to an outbreak of world lawlessness. "When an epidemic of physical disease starts to spread," FDR remarked, "the community approves and joins in a quarantine of the patients in order to protect the health of the community against the spread of the disease."1 Fearful of becoming embroiled in another world war, the United States was slow to shed its isolationism, only gradually increasing the provision

\footnotetext{
${ }^{1}$ For the text and audio of FDR's speech, see http://history.sandiego.edu/gen/text/us/fdr1937.html (last visited Jan. 29, 2005).
} 
of arms to its allies and restricting exports to the Axis powers. ${ }^{2}$ When war finally came at Pearl Harbor, Nazi and Japanese forces had expanded like a cancer throughout Europe and Asia, requiring far more than a quarantine to eliminate the malignancy.

Today the world confronts another danger that is on the brink of developing into an epidemic: the proliferation of weapons of mass destruction $\left(\mathrm{WMD}^{3}\right)$. With the Indian and Pakistani nuclear tests in 1998, the clandestine nuclear progress of North Korea and Iran, and over a dozen nuclear-capable states waiting indecisively on the sidelines, the world has arrived at what is fairly described as a "nuclear tipping point," where a few decisions to produce WMD could spark a cascade of proliferation. ${ }^{4}$ Such an outcome could have some stabilizing effects through the functioning of nuclear deterrence, but it would also create an expanding supply of material for catastrophic terrorism as well as raise the stakes between adversaries with fingers on the WMD trigger when conflicts do occur. Since convincing nascent WMD-states to disarm is an uncertain prospect, ${ }^{5}$ I argue that the United States and the international community should lay the

\footnotetext{
${ }^{2}$ See Robert A. Divine, Reluctant Belligerent: American Entry Into World War II (1979). For instance, although the United States instituted a "moral embargo" against Japan as early as July 1938, it was not until July 1941 that it imposed a complete embargo.

${ }^{3}$ Use of the collective term WMD carries the risk of overlooking important distinctions among nuclear, biological, and chemical weapons. At the same time, WMD is a simple, commonly understood, and analytically useful shorthand. I will note differences among the types of WMD when relevant, but will primarily focus on nuclear weapons.

${ }^{4}$ See The Nuclear Tipping Point: Why States ReConsider Their NuClear Choices (Kurt M. Campbell et al. eds., 2004).

${ }^{5}$ Reaching a negotiated settlement with states like North Korea and Iran along the lines of the December 2003 agreement with Libya would clearly be the most desirable outcome. See infra note 17. Unlike Libya, however, North Korea and Iran both have fairly advanced WMD programs that they will likely be reluctant to give up. Even so, it is
} 
foundation for a global quarantine ${ }^{6}$ against WMD, prohibiting all forms of transfer. Unfortunately, international law does not currently authorize such a system, forbidding only WMD transfers made to non-state actors. ${ }^{7}$ Thus, I propose that the United Nations Security Council, in conjunction with the International Maritime Organization, pass a resolution construing the deliberate proliferation of such weapons - to states and non-state actors alike-as a threat to the peace and an inherent act of aggression. A U.N. interdiction commission assessing requests to intercept weapons in transit, working in concert with the Proliferation Security Initiative ${ }^{8}$ can then enforce this mandate.

Toward these ends, this article aims to explain why a global quarantine is needed, why it is legitimate under international law, and how it can be established in an effective and ideally multilateral manner. Part I assesses the legal and institutional options currently available to the United States in combating the proliferation of WMD, briefly analyzing the strengths and weaknesses of each. It concludes that the inherent deficiencies of existing arms control tools require the creation of a new regime centered upon a robust interdiction authority. Part II then explores how the international community can both legally justify a global quarantine upon

imperative that U.S. negotiators put forward a viable package of incentives to test the willingness of Pyongyang and Tehran to disarm. If North Korea and Iran rebuff these proposals, it will be yet further proof that they are determined to gain a fully-fledged WMD capability.

${ }^{6}$ Inspiration to apply the quarantine concept to this topic is drawn partly from Ruth Wedgwood, A Pirate is a Pirate, Wall ST. J., Dec. 16, 2002, at A12.

${ }^{7}$ See infra Part II.B.2. The lack of a legal foundation for intercepting suspect shipments was brought into sharp relief in December 2002 during the So San incident. See infra Part I.E.

${ }^{8}$ The Proliferation Security Initiative, announced by President Bush in May 2003, is a multinational effort intended to equip states to prevent WMD proliferation. See infra note 35. 
principles of self-defense, and practically integrate it into existing institutions. This article thus represents the first effort to propose a comprehensive interdiction regime rooted in maritime law and the concept of confiscating contraband materials in self-defense.

\section{EXISTING FRAMEWORKS TO COMBAT WMD PROLIFERATION}

The proliferation of WMD is a multi-layered phenomenon, fueled by global trade, arms sales, indigenous research and development, and covert transfers to non-state actors. Defending against such a complex threat, in turn, involves a wide array of legal, institutional, and strategic mechanisms. States can adopt export controls to reduce proliferation generally, issue threats to deter the use of WMD, build defenses to minimize the damage from a WMD attack, take military action to disarm a potential adversary, or police the channels proliferators use to exchange weapons. This Part will analyze these frameworks, concluding that although each has merit, interdiction in particular is emerging as a crucial but legally underdeveloped option.

\section{A. Export Controls}

Some observers recommend strengthening export controls to keep sensitive technologies off the international market, thereby restraining the ability of states to produce WMD. ${ }^{9}$ While effective to an extent, the trouble is that increasingly proliferation is fueled by "dual-use" items,

${ }^{9}$ See, e.g., Daniel H. Joyner, Restructuring the Multilateral Export Control Regime System, 9 J. CONFLICT \& SECURITY L. 181 (2004). Efforts to dismantle and secure uranium from the former Soviet Union, such as the "NunnLugar Cooperative Threat Reduction Program," are another important mechanism to reduce the chance of nuclear materials falling into the hands of terrorists. See George Perkovich et AL., Universal Compliance: A STRATEGY FOR NUCLEAR SECURITY 54-56 (2004) (draft). However, as with export controls, these programs will not reach the potential WMD proliferation of new nuclear states producing fresh supplies of weapons-grade uranium and plutonium. 
goods with civilian purposes that also have military applications. ${ }^{10}$ Companies and governments, often more attuned to the immediate prospect of financial gain than the long-term security risks of questionable sales, do not always ensure that buyers are using their products for the intended purpose. ${ }^{11}$ Similarly, the Non-Proliferation Treaty (NPT) enables states to acquire sophisticated nuclear reactors and technology that are ostensibly for civilian power production, but which a state can ultimately divert to weapons development either in secret or if it chooses to terminate NPT safeguards. This potential loophole has led to proposals to place the supply of fissile material under international control, rather than continue to promote complete indigenous development. $^{12}$

Even if it were possible to reach international agreement over how to restrict dual-use items and regulate fissile material, the reality is that we live in a post-proliferation world and so in a sense the horse is out of the barn. North Korea is effectively a de facto nuclear state, likely to be in possession of sufficient reprocessed plutonium to create half a dozen bombs and hard at

\footnotetext{
${ }^{10}$ For instance, in 2000 Japan imposed export controls on its PlayStation2 video game system because it could process high quality images quickly, a feature much in demand for advanced missile guidance systems. PATRICK M. MORGAN, DETERRENCE NOW 234 (2003).

${ }^{11}$ U.S. General Accounting Office, Post-Shipment Verification Provides Limited Assurance That Dual-Use Items Are Being Properly Used, GAO Doc. GAO-04-357 (Jan. 2004), http://armedservices.house.gov/issues/gaoreportonpsvsJanuary2004.pdf.

${ }^{12}$ See, e.g., United Nations, A More Secure World: Our Shared ReSPonsibility, Report of the SecretaryGeneral's High-level Panel on Threats, Challenges and Change 44 (2004), http://www.un.org/secureworld/report2.pdf ; George Bush, Remarks on Weapons of Mass Destruction Proliferation (Feb. 11, 2004), http://www.whitehouse.gov/news/releases/2004/02/20040211-4.html.
} 
work developing enriched uranium as well. ${ }^{13}$ Most analysts also suspect Iran, despite repeated agreements with the European Union to suspend its nuclear development, ${ }^{14}$ of being well on its way toward mastering the enrichment process and hence on the verge of becoming a shadow, if not actual, nuclear power. ${ }^{15}$ The Pakistani nuclear mastermind Dr. A. Q. Khan's international bazaar may be no more, but it certainly appears to have had brisk sales while it was open for business. ${ }^{16}$ Thus, bar a disarmament agreement along the lines of that reached with Libya, ${ }^{17}$ in which Iran and North Korea agree to give up their weapons programs in return for aid and improved relations with the West (which appears fairly unlikely), export controls will not turn back the clock on these nascent nuclear states.

\section{B. Deterrence}

It does not necessarily follow that if some states acquire WMD, they will elect to use them. One might expect that the fear of devastating retaliation from a military superpower like

${ }^{13}$ Glenn Kessler, More N. Korean Bombs Likely, U.S. Official Says, WASH. Post, July 16, 2004, at A18; David E. Sanger \& William J. Broad, North Korea Said to Expand Arms Program, N.Y. TimES, Dec. 6, 2004 , at A1.

${ }^{14}$ Peter Ford, Europe Persuades Iran to Cool Nuclear Program-For Now, ChriSTIAN SCI. MONITOR, Nov. 16, 2004, at 7; Karl Vick, Iran's Leader Backs Deal on Inspections, WASH. PoST, Nov. 4, 2003, at A22.

${ }^{15}$ See Implementation of the NPT Safeguards Agreement in the Islamic Republic of Iran, IAEA Doc. GOV/2004/83 (Nov. 15, 2004), http://www.iaea.org/Publications/Documents/Board/2004/gov2004-83_derestrict.pdf; see also Douglas Frantz, Iran Moving Methodically Toward Nuclear Capability, L.A. TIMES, Oct. 21, 2004, at A1; Barbara Slavin, Iran's Nuke Plans May Be Unstoppable, USA TODAY, Aug. 30, 2004, at 13A.

${ }^{16}$ See Central Intelligence Agency, Unclassified Report to Congress on the Acquisition of Technology Relating to Weapons of Mass Destruction and Advanced Conventional Munitions, 1 July Through 31 December 2003 (2004), http://www.cia.gov/cia/reports/721_reports/pdfs/721report_july_dec2003.pdf; see also David E. Sanger \& William J. Broad, From Rogue Nuclear Programs, Web of Trails Leads to Pakistan, N.Y. TimES, Jan. 3 2004, at 1.

${ }^{17}$ See James G. Lakely, Libya Will Dismantle Its Weapons, WASH. TIMES, Dec. 20, 2003, at A1. 
the United States would dampen any aggressive impulses on the part of a regional power with WMD. In fact, it is very plausible that states like Iran and North Korea desire nuclear capabilities because they may help in deterring the United States from intervening in their affairs or initiating an invasion similar to that carried out against Iraq. The trouble with this perspective is that in focusing primarily on the direct bilateral military balance, it risks neglecting the role of thirdparty actors. In 2001 the Taliban in Afghanistan may have been effectively deterred from taking any offensive action against the United States, but it did not feel compelled to move against Al Qaeda, enjoying sanctuary within its borders at the time. If a fundamentalist regime like the Taliban were to come to power in Pakistan, it would not be far-fetched to envision a similar symbiotic relationship with a terrorist organization, potentially with the clandestine transfer of a nuclear weapon. States unwilling to face the virtually certain retaliation that a direct strike would invite may be willing to run the risk that an indirect attack might be difficult to trace to its origin.

Also, even if a proxy attack is not a state's intention, there may be financial incentives for states to attempt to sell nuclear materials on the black-market. This would be a remarkably dangerous game to play, but a state like North Korea may feel that it has no other choice given its dire economic situation. Nor are WMD sales merely a pessimistic hypothetical; not only did North Korea reportedly sell uranium to Libya ${ }^{18}$ and uranium hexafluoride to Pakistan, ${ }^{19}$ but in negotiations with the United States, a North Korean official threatened that its willingness to sell nuclear materials would depend on U.S. actions. ${ }^{20}$ This threat cannot be brushed aside, for if WMD were to end up in the hands of a terrorist organization like Al Qaeda, there can be little

\footnotetext{
${ }^{18}$ David E. Sanger, The North Korean Uranium Challenge, N.Y. TIMES, May 24, 2004, at A9.

${ }^{19}$ Donald Kirk, N. Korea Flirts With “Red Line,” Christian ScI. Monitor, May 28, 2004, at 7.

${ }^{20}$ David E. Sanger, North Korea Says it Now Possesses Nuclear Arsenal, N.Y. TIMES, Apr. 25, 2003 , at A1.
} 
doubt that it would attempt to use them. In sum, relying on the power of deterrence to prevent WMD attacks places a great deal of faith in a doctrine that is far from infallible and of little meaning to terrorists.

C. Defenses

Relying on deterrence would not be as worrisome if there were robust defensive systems in place to prevent WMD attacks or minimize their damage when deterrence failed. Unfortunately, despite significant progress in some areas, many experts believe that the United States has a long way to go in providing an adequate homeland security framework. ${ }^{21}$ The Bush Administration's multi-billion dollar national missile defense system lies at the center of controversy, as skeptics claim that its low reliability ${ }^{22}$ and susceptibility to countermeasures will not provide any meaningful strategic benefits. $^{23}$ The critical issue is whether potential adversaries will rely on a long-range missile threat, as opposed to other means of delivery such as cruise missiles or infiltration. Given the challenges inherent in patrolling U.S. borders and coastlines and the fact that customs officials inspect only about $2 \%$ of containers shipped to the

${ }^{21}$ See, e.g., Stephen Flynn, America the Vulnerable: How OUR Government is Failing to Protect Us From TERrorism (2004); GARY HART \& WARREN B. RudMAN, COUNCIL ON FOREIGN RELATIONS, AMERICA STILl UNPREPARED—AMERICA STILL IN DANGER (2002).

${ }^{22}$ Thus far, test results of the missile defense system have not been promising. See David Stout \& John H. Cushman, Jr., Defense Missile For U.S. System Fails to Launch, N.Y. TIMES, Dec. 16, 2004, at A1.

${ }^{23}$ See Richard L. Garwin, A Defense That Will Not Defend, WASH. Q., Summer 2000, at 109; George Lewis, Lisbeth Gronlund, and David Wright, National Missile Defense: An Indefensible System, FoREIGN POL'Y, Winter 19992000 , at 120 . 
United States, ${ }^{24}$ there is an understandable concern that missile defenses might embody a "Maginot Line" mentality that aggressive states could easily bypass altogether.

Domestically, the United States is a soft target with many points of vulnerability that could result in greater damage than even a missile strike. Bio-terrorism against agriculture, chemical attacks on public transportation systems or at public events, and "dirty" radiological bombs all remain major fears. This is not to say that the United States has failed to take steps to protect itself - the Department of Homeland Security has implemented many important reforms ${ }^{25}$ - but to point out that policy makers should not see domestic defensive measures as a reliable failsafe. The attacks of September 11, 2001 were a harsh reminder of how difficult it is to predict the manner in which terrorists choose to strike, and it may be that no amount of defense will suffice against a determined attacker.

\section{Counterforce}

Considering the limitations of other protective measures, some commentators maintain that the risk of certain states using WMD or supplying them to terrorists may be substantial enough to justify disarmament by air strikes or even outright invasion. ${ }^{26}$ This option is nothing

\footnotetext{
${ }^{24}$ Justin S.C. Mellor, Missing the Boat: The Legal and Practical Problems of the Prevention of Maritime Terrorism, 18 AM. U. INT'L L. REV. 341, 342 (2002). Through the Container Security Initiative, the United States has recently reformed its customs rules to require every shipping company importing cargo to provide U.S. officials with advance information on each container on their ships, along with other security measures. Mark Hosenball \& Evan Thomas, High-Seas Hunting, NEWSWEEK, Dec. 23, 2003, at 44.

${ }^{25}$ Press Release, Dep't of Homeland Security, Fact Sheet: A Better Prepared America: A Year in Review (July 20, 2004), http://www.dhs.gov/dhspublic/interapp/press_release/press_release_0465.xml.

${ }^{26}$ See, e.g., William C. Bradford, 'The Duty to Defend Them': A Natural Law Justification For the Bush Doctrine of Preventive War, 79 Notre Dame L. ReV. 1365, 1470 (2004); Guy B. Roberts, The Counterproliferation Self-Help
} 
new to U.S. military planners, who seriously contemplated contingency plans to destroy the nuclear facilities of the Soviet Union at the start of the Cold War, ${ }^{27}$ China in the early 1960 s, ${ }^{28}$ and North Korea during the crisis of 1993-94. ${ }^{29}$ However, until recently with the U.S. invasion of Iraq, there have been very few efforts to sanction this type of preventive military operation under international law. When Israel carried out a successful strike on Iraq's Osiraq nuclear reactor in 1981, destroying it just before plutonium production was to begin, world opinion rejected Israel's assertion of self-defense. ${ }^{30}$ As might be expected, the United States has since become much more sympathetic to such claims. Former Secretary of State Colin Powell remarked in 2002: "The Israelis did it in 1981. It was a clear preemptive military strike. Everyone now is quite pleased even though they got the devil criticized out of them at the time.",31

Putting aside the legality of such an attack for the moment, it is becoming increasingly likely that Osiraq-style missions are a thing of the past. This is partly because of the potential for

Paradigm: A Legal Regime for Enforcing the Norm Prohibiting the Proliferation of Weapons of Mass Destruction, 27 DenV. J. INT'L L. \& Pol’y 483, 518 (1999); John C. Yoo, Using Force, 71 U. CHI. L. Rev. 729, 794 (2004).

${ }^{27}$ See Russell D. Buhite and William Christopher Hamel, War for Peace: The Question of an American Preventive War Against the Soviet Union, 1945-1955, DIPLOMATIC HISTORY, Summer 1990, at 367.

${ }^{28}$ See William Burr and Jeffrey T. Richelson, Whether to 'Strangle the Baby in the Cradle:' the United States and the Chinese Nuclear Program, 1960-64 INT'L SECURITY, Winter 2000-01, at 54, 68.

${ }^{29}$ See Selig S. Harrison, Korean EndGame: A Strategy for Reunification and U.S. Disengagement 122 (2002).

${ }^{30}$ See Uri Shoham, The Israeli Raid Upon the Iraqi Nuclear Reactor and the Right to Self-Defense, MIL. L. REV., Summer 1985, at 191.

${ }^{31}$ Glenn Kessler \& Peter Slevin, Preemptive Strikes Must Be Decisive, Powell Says, WaSh. Post, June 15, 2002, at A16. 
devastating reprisals. For example, besides its uncertain nuclear forces, North Korea possesses an artillery arsenal believed to contain some 10,000 long-range rockets, capable of devastating the South Korean capital of Seoul, a mere fifty miles from the De-Militarized Zone. ${ }^{32}$ Also, having learned from Osiraq, states fearful of becoming a target for such an attack are increasingly dispersing their weapons facilities, placing them in hardened underground bunkers, or locating them near civilian buildings to pose the risk of collateral damage. ${ }^{33}$ Iran's suspected enrichment facilities are effectively immune from air strikes, hidden in large government complexes and in other secret locations. ${ }^{34}$ Granted, an outright invasion would probably uproot the WMD development of both Iran and North Korea, but in the wake of the war in Iraq, this appears politically, militarily, and financially unlikely for the near future.

\section{E. Interdiction}

Given these grim conclusions-the failure of export controls, the inadequacy of deterrence, the uncertainty of defenses, and the impracticality of counterforce-it is crucial that the United States have robust interdiction capabilities to prevent the transfer of WMD. Recognizing this need, President Bush announced on May 31, 2003 in Krakow, Poland the Proliferation Security Initiative (PSI), a multinational effort to equip states to prevent WMD proliferation. ${ }^{35}$ The founding participants of the PSI issued a "Statement of Interdiction Principles," identifying specific areas of cooperation, particularly in sharing intelligence

\footnotetext{
${ }^{32}$ Kim Myong Chol, Kim Jong Il's Military Strategy for Reunification, COMP. STRATEGY, Oct. 2001, at 303, 313.

${ }^{33}$ See Lee Feinstein \& Anne-Marie Slaughter, A Duty to Prevent, ForeIGN AFF., Jan./Feb. 2004, at 147.

${ }^{34}$ David E. Sanger, U.S. vs. a Nuclear Iran, N.Y. TIMES, Dec. 12, 2004, at 8.

${ }^{35}$ See Press Release, U.S. Dep't of State, Bureau of Nonproliferation: The Proliferation Security Initiative (July 28, 2004), at http://www.state.gov/t/np/rls/other/34726.htm.
} 
information and providing mutual consent in interdiction missions. ${ }^{36}$ Already the PSI has had some notable successes, including the September 2003 interception of a freighter bound for Libya with a shipment of uranium enrichment parts, which some observers believe was responsible for Libyan leader Moammar Gaddafi's decision to accept inspections and disarm. ${ }^{37}$

The PSI is meant to "be consistent with existing national legal authorities and international law and frameworks." ${ }^{38}$ Generally, while a state has complete jurisdiction over its airspace, territory, and internal waters, its authority diminishes in relation to the distance from its coastline. ${ }^{39}$ Under the principle of exclusive flag state jurisdiction, vessels on the high seas ${ }^{40}$ "are subject to no authority except that of the State whose flag they fly." 41 The primary exceptions to this rule are listed in Article 110 of the U.N. Convention on the Law of the Sea (UNCLOS),

36 The White House, Office of the Press Secretary, Fact Sheet: Proliferation Security Initiative: Statement of Interdiction Principles (Sept. 4, 2003), http://www.state.gov/t/np/rls/fs/23764.htm.

${ }^{37}$ See Robin Wright, “Ship Incident May Have Swayed Libya,” WASH. Post, Jan. 1, 2004, at A18.

${ }^{38}$ U.S. Dep't of State, Bureau of Nonproliferation, Fact Sheet: Proliferation Security Initiative Frequently Asked Questions (FAQ) (May 24, 2004), at http://www.state.gov/t/np/rls/fs/32725.htm.

39 See Daniel H. Joyner, The Proliferation Security Initiative: Nonproliferation, Counterproliferation and International Law, 50 YALE J. INT'L L. (forthcoming 2005) (manuscript at 25, on file with author).

${ }^{40}$ According to the U.N. Law of the Sea Convention, the high seas are beyond a state's "exclusive economic zone," which is a maximum of 200 nautical miles from its twelve-mile territorial sea. United Nations Convention on the Law of the Sea, art. 3, 57, 86, U.N. Doc. A/CONF. 62/122, opened for signature Dec. 10, 1982, 1833 U.N.T.S. 397 (1994) [hereinafter UNCLOS].

41 S.S. Lotus Case (Fr. v. Turk.), 1927 P.C.I.J. (ser. A) No. 9, at 25 (Sept. 7). This principle was codified in UNCLOS supra note 40, art. 92(1). See Michael Byers, Policing the High Seas: The Proliferation Security Initiative, 98 AM. J. INT’L L. 526, 527 n.9 (2004). Byers also notes that the regime of high seas freedom also applies to aircraft beyond a state's territorial seas. $I d$. at $527 \&$ n. 13 . 
granting warships the right to board and search a vessel when there is reasonable ground for suspecting that it is engaging in piracy, slave trading, unauthorized broadcasting, lacks a flag, or is flying a false flag. ${ }^{42}$ Unless one is willing to expand the definition of piracy to include WMD proliferation, which is probably quite a stretch, ${ }^{43}$ this means that UNCLOS bars any state from interdicting suspected WMD traffickers on the high seas without the consent of the ship's flag state.

The potential consequences of this restriction were brought into sharp relief in December 2002, when U.S. intelligence identified an unflagged North Korean freighter (the So San) crossing the Arabian Sea and contacted the Spanish government to request that its navy stop the vessel and inspect it for illicit cargo. ${ }^{44}$ Spanish special forces boarded the ship, uncovering a cache of Scud missiles hidden beneath sacks of cement. Shortly thereafter, Yemeni government officials came forward and claimed ownership, declaring that they had purchased the missiles from North Korea for defensive purposes. Since international law does not bar such a sale, the United States and Spain allowed the So San to proceed, accepting an agreement from the Yemeni president not to make further purchases. This incident was disturbing not for its specific factsthe boarding itself was legal because the ship was flagless-but rather because it highlighted the limited legal authority that would exist for similar operations in the future. If the So San had been flying a North Korean flag, and refused to consent to boarding, UNCLOS would prohibit interdiction, even if there was a strong certainty that it carried WMD.

\footnotetext{
${ }^{42}$ UNCLOS, supra note 40, art. 110(1).

${ }^{43}$ See Joyner, supra note 39 , at 34.

${ }^{44}$ See Jofi Joseph, The Proliferation Security Initiative: Can Interdiction Stop Proliferation? ARMS CONTROL TODAY, June 2004, at 7; Thom Shanker, Threats and Responses: Arms Smuggling; Scud Missiles Found on Ship of North Korea, N.Y. TIMES, Dec. 11, 2002, at A1.
} 
Making the best of its limited legal authority, the PSI is focusing on streamlining the process for acquiring the consent of flag states to board their vessels, thereby bypassing UNCLOS altogether. Besides the provisions addressing mutual consent in the PSI's "Statement of Interdiction Principles, ${ }^{45}$ the United States has signed three ship-boarding agreements with major shipping registry states (Liberia, Panama and the Marshall Islands), establishing bilateral procedures for boarding vesselssuspected of carrying WMD or related materials. ${ }^{46}$ Modeled after counter-narcotics arrangements, these agreements have the effect of limiting the number of flag states a proliferating state can rely upon in transporting illicit materials under the protection of UNCLOS. However, securing the assent of other key shipping registry states could be difficult given that many states that offer "flags of convenience" (allowing registration with little regulation or oversight) are highly dependent on the earnings from such transactions and may be

\footnotetext{
${ }^{45}$ See supra note 36.
}

46 Agreement Between the Government of the United States of America and the Government of the Republic of Liberia Concerning Cooperation To Suppress the Proliferation of Mass Destruction, Their Delivery Systems, and Related Materials By Sea, Feb. 11, 2004, http://www.state.gov/t/np/trty/32403.htm; Amendment to the Supplementary Arrangement Between the Government of the United States of America and the Government of the Republic of Panama to the Arrangement Between the Government of the United States of America and the Government of Panama for Support and Assistance from the United States Coast Guard for the National Maritime Service of the Ministry of Government and Justice, May 12, 2004, http://www.state.gov/t/np/trty/32858.htm; Agreement Between the Government of the United States of America and the Government of the Republic of the Marshall Islands Concerning Cooperation to Suppress the Proliferation of Weapons of Mass Destruction, Their Delivery Systems, and Related Materials by Sea, Aug, 13, 2004, http://www.state.gov/t/np/trty/35237.htm. Each of these agreements enables a party to request that the other confirm the nationality of the ship in question and, if needed, authorize interdiction. 
reluctant to grant consent. ${ }^{47}$ Unless the United States can reach ship-boarding agreements with virtually all flag states, traffickers will retain options for shipping WMD effectively immune from interdiction authority. ${ }^{48}$ Moreover, even if universal participation were possible, the most likely proliferators, such as Pakistan, Iran and North Korea, could always elect to transport WMD shipments under their own flag, thereby guaranteeing that consent would not be forthcoming.

Realistically, if the United States were to receive intelligence reports indicating that a North Korean ship was transporting a completed nuclear device on the high seas, the lack of consent would surely not be a barrier to its decision to interdict. This poses a gap between the stated objectives of the PSI and its legal authority to achieve them. The threat posed by WMD is simply too great to allow a pocket of immunity under UNCLOS to prevent all interdiction efforts without consent, regardless of the magnitude of the threat. The notion that some states should profit from lending the use of their flag as a shield against inspection is likewise untenable in an age of WMD. Instead, there should be a global norm against WMD proliferation that is allinclusive, holding any state that transports WMD responsible, regardless of nationality. The rest of this article will focus on achieving this goal through a global quarantine.

This is not meant to imply that interdiction will suffice as an exclusive or even primary strategy to combat WMD. Interdiction missions require extraordinary intelligence, timing and coordination to be successful. Detecting plutonium is incredibly difficult given its faint radiation

\footnotetext{
${ }^{47}$ See Andreas Persbo \& Ian Davis, SaIling Into Uncharted Waters? The Proliferation Security INITIATIVE AND THE LAW OF THE SEA 8-9 (2004).

${ }^{48}$ See Joel A. Doolin, Operational Art for the Proliferation Security Initiative 5 (2004) (unpublished final paper, Naval War College), available at http://www.fas.org/man/eprint/doolin.pdf.
} 
emission, ${ }^{49}$ and monitoring biological and chemical weapons is even more challenging since their precursor elements are often dual-use in nature, posing the same dilemmas that plague export control decisions. ${ }^{50}$ Far preferable are negotiated disarmament agreements and confidence building measures that could eliminate the desire of states to acquire WMD in the first place. However, given the limitations of arms control measures illustrated in this Part, if states do choose to develop and sell WMD, interdiction may be the last viable line of defense against their use. The alternative of active disarmament operations is far more dangerous, invasive, legally questionable, and likely to spur yet further proliferation to deter such action.

\section{A New ApProach: Global Quarantine}

Given that the provisions of UNCLOS will not support a robust interdiction regime, the key issue is how to establish a legal foundation for a global quarantine against WMD. This Part examines how the doctrine of self-defense provides conceptual justification for a quarantine, and then explores how to integrate these principles into a functioning institutional framework.

\section{A. The Evolving Law of Self-Defense}

Article $51,{ }^{51}$ the U.N. Charter provision concerning self-defense, has become highly controversial, particularly given the events surrounding the U.S. invasion of Iraq. Some legal

\footnotetext{
${ }^{49}$ See Michael Levi, Uncontainable: North Korea's Loose Nukes, New RePUblic, May 26, 2003, at 11.

${ }^{50}$ Interview with Ashley Roach, Attorney-Adviser, Office of the Legal Adviser, U.S. Dep't of State, in Washington D.C. (Oct. 25, 2004).

${ }^{51}$ U.N. CHARTER art. 51, http://www.un.org/aboutun/charter/ (last visited Jan. 29, 2005) ("Nothing in the present Charter shall impair the inherent right of individual or collective self-defence if an armed attack occurs against a Member of the United Nations, until the Security Council has taken measures necessary to maintain international peace and security. Measures taken by Members in the exercise of this right of self-defence shall be immediately
} 
scholars claim that the specter of terrorists gaining access to WMD has undermined the central premise of Article 51, leaving states unwilling to absorb an attack before taking action. ${ }^{52}$ Along these lines, the U.S. National Security Strategy aims to re-conceptualize the notion of imminent threat, reserving what it describes as an option to take preemptive (or, more accurately, preventive ${ }^{53}$ ) actions against threats to national security. ${ }^{54}$ That is not to say that Article 51 lacks supporters. The U.N. High-level Panel on Threats, Challenges and Change, a blue ribbon commission convened by Secretary-General Kofi Annan to analyze emerging security concerns and propose U.N. reforms, stated unequivocally in its December 2004 report that Article 51 "needs neither extension nor restriction of its long-understood scope." 55 This section will assess these clashing positions, outlining how a global quarantine is supported by international law.

The drafters of the U.N. Charter, which celebrates its sixtieth anniversary on June 26, 2005, faced a very different international system than that which currently exists. The United States had not yet dropped the atomic bomb on Japan, nor had the Soviet or American military yet mastered the technology behind Hitler's long-range V-2 rockets. ${ }^{56}$ Instead, the greatest danger facing states at the time was the threat of land invasion or aerial bombardment, both of reported to the Security Council and shall not in any way affect the authority and responsibility of the Security Council under the present Charter to take at any time such action as it deems necessary in order to maintain or restore international peace and security.”).

${ }^{52}$ See, e.g., Michael J. Glennon, The Fog of War: Self-Defense, Inherence, and Incoherence in Article 51 of the United Nations Charter, 25 HARV. J.L. \& PUB. POL’y 539, 541 (2002).

${ }^{53}$ See Lawrence Freedman, Prevention, Not Preemption, WASH. Q., Spring 2003, at 105.

${ }^{54}$ U.S. Government, The National Security Strategy of the United States of America 15 (2002), http://www.whitehouse.gov/nsc/nss.pdf.

${ }^{55}$ United Nations, A MORE SECURE World, supra note 12, at 3.

${ }^{56}$ DAVID Reynolds, One World Divisible: A Global History Since 194510 (2000). 
which had an obvious point of origin and often a tell-tale mobilization period. Biological and chemical weapons existed, but the fear of retaliation based on the harrowing experience of World War I kept their use at bay, and there was not yet an international terrorist movement that could employ such materials without accountability. The terminology of Article 51 was thus enmeshed in an international context with a very overt and unambiguous notion of what qualified as an armed attack. ${ }^{57}$ Today, the prime danger to the United States is not an army charging across the border, but an individual stepping off a plane with a suitcase of plutonium. Against what columnist Thomas Friedman artfully describes as "people of mass destruction," 58 there is likely to be little warning, limited ability to defend, and an uncertain target for retaliation.

W. Michael Reisman notes that innovations in science and technology often create a "legal gap in which authority becomes uncertain. ... When some of these factors change to the point that communities can no longer assure their defense within the ambit of inherited law, those charged with national defense inevitably demand changes in the law." ${ }^{, 5}$ The unique security circumstances surrounding air travel, for instance, has required corresponding modifications in the interpretation of privacy law. ${ }^{60}$ The inherent difficulties of border control,

\footnotetext{
${ }^{57}$ Similarly, although based on ancient maritime principles, UNCLOS is a product of the Cold War, concerned with safeguarding innocent passage and free navigation amidst superpower tensions. See UNCLOS, supra note 40, art. 17, 87. For instance, today it may seem a bit anachronistic for a document to authorize the boarding of a ship and prosecution of individuals if they are broadcasting illegally, but not if they are transporting a nuclear bomb. Id., art. 109.

${ }^{58}$ Thomas L. Friedman, The Suicide Supply Chain, N.Y. TimeS, Dec. 9, 2004, at A41.

${ }^{59}$ W. Michael Reisman, Editorial Comment: Assessing Claims to Revise the Laws of War, 97 AM. J. INT’L L. 82, 82 (2003).

${ }^{60}$ See, e.g., United States v. Edwards, 498 F.2d 496 (2d Cir. 1984).
} 
likewise, have necessitated a relaxed standard of reasonable suspicion for checkpoint searches. ${ }^{61}$ It is inevitable that the threats posed by WMD and terrorism will also open up legal gaps that policy makers and national security officials will draft legislation to bridge. ${ }^{62}$ The USA Patriot Act, ${ }^{63}$ officially titled "Uniting and Strengthening America by Providing Appropriate Tools Required to Intercept and Obstruct Terrorism," is one such example.

The crucial issue is how to ensure that such legal remedies do not extend beyond the apparent gap and begin to overreach, perhaps infringing upon civil liberties. ${ }^{64}$ In the domestic setting, courts assist legislators in determining the proper constitutional bounds of enforcement activity; the U.S. Supreme Court has upheld brief, suspicion-less searches at highway checkpoints to combat drunk driving, ${ }^{65}$ but has declined to extend that authority to interdict illegal narcotics. ${ }^{66}$ This kind of fine-tuned balancing is particularly problematic in the international arena, which lacks comparable institutional authorities. Within the anarchic international system, guiding rules are more malleable and infused with the irreducible potential

\footnotetext{
${ }^{61}$ See, e.g., United States v. Martinez-Fuerte, 428 U.S. 543 (1976).

${ }^{62}$ See Ronald M. Gould \& Simon Stern, Catastrophic Threats and the Fourth Amendment, 77 S. CAL. L. REV. 777 , 777 (2004) ("The traditional Fourth Amendment search-and-seizure doctrine was fine for an age of flintlocks, and maybe even for an age of automatic weapons. . . . But one must wonder whether our traditional constitutional doctrine, without more, is up to the task of governing all searches and seizures in an age of weapons of mass destruction and potential terrorism."); Ronald J. Sievert, Meeting the Twenty-First Century Terrorist Threat Within the Scope of Twentieth-Century Constitutional Law, 37 HOUS. L. REV. 1421 (2000).

${ }^{63}$ USA Patriot Act of 2001, Pub. L. No. 107-56, 115 Stat. 272 (2001).

${ }^{64}$ See, e.g., Bruce Ackerman, The Emergency Constitution, 113 YALE L.J. 1029 (2004); Harold Hongju Koh, The Spirit of the Laws, 43 HARV. INT'L L.J., 23, 34 (2002).

${ }^{65}$ Michigan Dept. of State Police v. Sitz, 496 U.S. 444 (1990).

${ }^{66}$ City of Indianapolis v. Edmond, 531 U.S. 32 (2000).
} 
of military force. In modern international law, Reisman observes, "Doctrines are positioned at the interface of law and power." ${ }^{67}$ The critical factor in whether a new claim is accepted and incorporated into the corpus of international law is not its constitutionality but whether it serves the "common interests of the aggregate of actors" and the "essential goals of law."68 To determine whether a global quarantine would serve the interests of international law and the world community, it is necessary to return to the basic principles of self-defense.

Generally, individuals are not supposed to use force in response to threats to their wellbeing due to concerns of vigilantism. However, when the police are unavailable, individuals are entitled to protect themselves even through violent action. Likewise, Article 2(4) and 39 of the U.N. Charter reserve the authority to decide how to respond to breaches of the peace to the Security Council, not to individual states. ${ }^{69}$ As with individuals, though, when a state is in danger, the imperative of self-defense can transcend general prohibitions on the use of force and the state can take immediate, forceful action in response. ${ }^{70}$ This right, moreover, is not limited to purely local, reactive measures, but can extend abroad. According to Chief Justice Marshall, in an opinion in 1804, a state's power to secure itself from injury "may certainly be exercised beyond the limits of its territory."71 This principle underlies the right of a belligerent to search a

\footnotetext{
${ }^{67}$ Reisman, supra note 59 , at 90.

${ }^{68}$ Id., at 89.

${ }^{69}$ U.N. CHARTER, supra note 51, art. 2(4), 39.

${ }^{70}$ The protective principle in international law, which bases jurisdiction on the adverse effect an individual's action has on a nation's security, is in effect a derivative, collective exercise of personal self-defense. See Christina E. Sorensen, Drug Trafficking on the High Seas: A Move Toward Universal Jurisdiction Under International Law, 4
} EMORY INT'L L REV 207, 217 (1990).

${ }^{71}$ Church v. Hubbard, 6 U.S. 187, 234 (1804). 
neutral vessel on the high seas for contraband in an effort to interdict goods that could support an enemy's war campaign. $^{72}$

Counter-balancing the right of self-defense is the notion of sovereignty, based on the principle that a state should be free from interference in its domestic affairs if it has not violated the rights of another state. ${ }^{73}$ It is not always clear what degree of deference to sovereignty is appropriate, however, given the U.N. Charter's parallel mandate in Article 2(4) that all member states shall refrain from the threat of force "against the territorial integrity or political independence of any state." 74 Certainly sovereignty should not act as a shield protecting a state from all foreign intervention up until the point that it attacks another state, regardless of its other actions. If a modern-day Hitler were to come to power and begin to develop nuclear weapons, FDR's quarantine notion — and perhaps yet more active measures_would be only sensible. Increasingly, scholars are defining sovereignty as a source of responsibility as much as a claim of immunity. ${ }^{75}$ Under this conception, states may lose their sovereign status if they fail to protect their citizens or become a menace to the international community by trafficking in WMD. A

\footnotetext{
${ }^{72}$ Id., at 234-35. See also Lois E. Fielding, Maritime Interception: Centerpiece of Economic Sanctions in the New World Order 53 LA. L. REV. 1191, 1204 (1993). There have been numerous historical assertions of this authority. For instance, in 1873, Spain seized the U.S. Virginius, which was carrying British nationals and weapons intended for use in the Cuban insurrection against Spain. R.R. CHURCHILL \& A.V. LOWE, THE LAW OF THE SEA 216 (3d ed. 1999). From 1952-1962, France asserted a right to visit and search ships suspected of carrying arms to Algeria. Id. More recently, in January 2002 Israel seized the Karin-A, an Iraqi-flagged ship that had around fifty tons of Iranian weapons on board, allegedly bound for the Palestinian Authority. Byers, supra note 41, at 533.

${ }^{73}$ U.N. CHARTER, supra note 51, art 2(7).

${ }^{74} I d .$, art 2(4).

75 See INTERNATIONAL COMMISSION ON INTERVENTION AND STATE SOVEREIGNTY, THE RESPONSIBILITY TO PROTECT 13 (2001), available at http://www.dfait-maeci.gc.ca/iciss-ciise/pdf/Commission-Report.pdf.
} 
correlated duty of other states might be to forcibly prevent such nations from carrying out genocide against their citizens or selling their weapons. ${ }^{76}$

Arguably, WMD in the hands of brutal and aggressive regimes may pose an inherent threat to world peace, placing them at odds with Article 2(4). The question, though, is where to draw the line that triggers the authority of other states to respond in self-defense. Article 51 on its face allows self-defense only in response to an armed attack. ${ }^{77}$ The main rationale for a plain reading of Article 51 is to eschew the unavoidable elasticity of self-interested interpretations of what constitutes a threat to a state's security. As Michael Glennon puts it, "What is self-defense to one state is aggression, armed reprisal, armed attack, intervention, or forcible countermeasures to another." ${ }^{, 78}$ States with axes to grind may set the threshold of danger artificially low, instigating wars that might have been avoided through diplomacy, containment, or other means. ${ }^{79}$ Instead, requiring the actual employment of force establishes a bright-line rule that is at least theoretically unambiguous. The trouble with this standard is that such a restrictive notion of self-defense is difficult to sustain in the modern day. According to one scholar, "The destructive nature of $[\mathrm{WMD}]$ requires that the point of unacceptable danger move further in time from the actual moment of aggressive use." ${ }^{80}$ The United States cannot be expected to wait until an attack like September 11th occurs before acting against a terrorist organization like Al Qaeda. In such

\footnotetext{
${ }^{76}$ See Feinstein \& Slaughter, supra note 33, at 137.

${ }^{77}$ See supra note 51.

${ }^{78}$ Glennon, supra note 52, at 558.

${ }^{79}$ This, of course, is the charge many legal scholars level against the United States regarding Operation Enduring Freedom in Iraq. See, e.g., Lucy Martinez, September 11th, Iraq, and the Doctrine of Anticipatory Self-Defense, 72 U. Mo. Kansas City L. ReV. 123, 182 (2003).

${ }^{80}$ Roberts, supra note 26 , at 538.
} 
circumstances, deterrence is untenable and there is little chance of reaching settlement or providing an adequate defense.

To provide flexibility to Article 51's bright-line rule, the U.N. High level Panel invoked customary law to identify a state's right to defend itself against imminent threats. ${ }^{81}$ Based upon former U.S. Secretary of State Daniel Webster's principles articulated in the famous Caroline Case, states can respond with proportionate force to a threat that leaves no choice of means and not a "moment for deliberation." 82 Again, the problem is that even the standard of imminent threat may be inadequate in responding to WMD proliferation. ${ }^{83}$ The Caroline principles are still highly restrictive, and it is difficult to conceive of many real-world scenarios that would meet their criteria. As Elaine Bunn points out, "the closer to the 'imminent use' end of the spectrum a situation falls, the easier preemption is to justify politically, but the harder it may be to be operationally decisive, because the adversary will likely have protected the intended targets of preemption ....."84 A traditional standard of imminence still requires the United States to wait

81 United Nations, A More Secure World, supra note 12, at 63 (“[A] threatened State, according to long established international law, can take military action as long as the threatened attack is imminent, no other means would deflect it and the action is proportionate.”) (emphasis in original). See also DEREK W. BOWETT, SELFDefEnce IN International LaW 185 (1958); Richard G. Maxon, Nature's Eldest Law: A Survey of a Nation's Right to Act in Self-Defense, PARAMETERS, Autumn 1995, at 55.

${ }^{82}$ Letter from Daniel Webster to Lord Ashburton. Aug. 6, 1842, reprinted in John Bassett Moore, ed., 2 INT'L L. DiGEST 412 (1906), available at http://www.danorr.com/webster/webster_august6_1842.html. For a discussion of the case, see R.Y. Jennings, The Caroline and McLeod Cases, 32 AM. J. INT'L L. 82, 89 (1938).

${ }^{83}$ See W.T. Mallison, Jr., Limited Naval Blockade or Quarantine-Interdiction: National and Collective Defense Claims Valid Under International Law, 31 GEO. WASH L. REV. 335, 348 (1962).

${ }^{84}$ M. Elaine Bunn, Preemptive Action: When, How, and to What Effect?, STRATEGIC ForUM, July 2003 , at 4. Moreover, the level of force required to destroy a terrorist threat may not always be strictly proportional. 
until the September 11th terrorists are about to board their planes, rather than go after the source of the threat. President George Bush articulated this concern in his 2003 State of the Union address: "Some have said we must not act until the threat is imminent. Since when have terrorists and tyrants announced their intentions, politely putting us on notice before they strike?" ${ }^{, 85}$ At the same time, this does not mean that WMD possession is any more feasible of a standard than use or imminent use. As Section I illustrated, counterforce against states with WMD is extremely problematic, meaning that to be feasible the United States would probably have to attack a state as it was in the process of developing WMD, a remarkably expansive form of self-defense that is particularly liable to abuse and flawed intelligence assessments. ${ }^{86}$

The High-level Panel acknowledged that "The problem arises where the threat in question is not imminent but still claimed to be real ...." ${ }^{87}$ In such cases, the Panel urged not the abandonment of Article 51, but recourse to Article 39 of the U.N. Charter. Since Article 39 empowers the Security Council to recommend military measures in response to "any threat to the peace, breach of the peace, or act of aggression," ${ }^{, 88}$ a state that cannot legally pursue independent action under Article 51 can always turn to the Security Council for authorization, even for a preventive military operation. ${ }^{89}$ The dilemma with this alternative, as the world is well aware

85 George W. Bush, State of the Union Address (Jan. 28, 2003),
http://www.whitehouse.gov/news/releases/2003/01/20030128-19.html.

${ }^{86}$ These two concerns constitute the most significant criticisms of expanding interdiction authority as well. For a further discussion of the intelligence challenges, see infra Part II.B.2. On the potential for abuse, see infra Conclusion.

${ }^{87}$ United NATIONS, A MORE SECURE WORLD, supra note 12, at 63.

${ }^{88}$ U.N. CHARTER, supra note 51, art. 39.

${ }^{89}$ United NAtions, A MORE SECURE WorLd, supra note 12, at 62. 
from the wrangling at the Security Council in the months prior to the 2003 U.S. invasion of Iraq, is the potential for Council stalemate or a veto in an authorization vote. According to the Panel, if the Security Council elects to withhold its consent for a preventive action, "there will be, by definition, time to pursue other strategies, including persuasion, negotiation, deterrence and containment—and to visit again the military option." 90 While this reasoning might be convincing in considering whether to attack and disarm a state that is gradually developing a WMD arsenal, in which case there might be time to make a subsequent request to the Security Council down the road, with interdiction missions there may be no second chance; once the weapons go they are gone.

Article 39 alone, then, is insufficient to deal with fleeting windows of opportunity of the kind associated with interdiction. Without a more robust and streamlined process, rather than risk delay and dissension at the Security Council, the United States would probably act on its own (or with other PSI participants), claiming a rationale of self-defense. ${ }^{91}$ To prevent this outcome, the United Nations should provide an avenue for multilateral interdiction efforts, adopting a brightline rule against the transfer of WMD. Such a reform is in accord with the U.N. Charter because the proliferation of WMD is not defensive; rather, it is a form of aggression against world order that merits a limited form of protection in the same vein. When a state elects not merely to build but to transfer WMD, placing other states in danger, it sacrifices the sovereignty its ships and planes would traditionally enjoy in international waters and airspace. In a sense, even though there may not be a traditional state of belligerency, the United Nations should treat WMD as international contraband, permitting search and seizure when there is reasonable suspicion of

\footnotetext{
${ }^{90}$ Id. at 63 .

${ }^{91}$ See infra Part II.B.3.
} 
their $_{\text {presence. }}^{92}$ To be sure, the potential for an abuse of interdiction power will remain, even when carried out multilaterally. Establishing a global quarantine in principle will not eliminate the problems of proof surrounding authorization of interdiction operations in practice, but it is a step in the right direction. The next Section will attempt to map out a potential path for those steps to take.

\section{B. Building Blocks of a Global Quarantine}

An effective global quarantine system will require an integrated framework of initiatives, supplying both the legal foundation to establish a global norm against WMD proliferation and the needed capabilities to carry out interdiction missions. There are doubtless numerous combinations of means to achieve this end, but this Section will focus on those I believe are most promising: first, the International Maritime Organization (IMO) can articulate general principles forbidding the transfer of WMD on the high seas; second, the U.N. Security Council can pass a resolution binding the international community to these rules, thereby extending Resolution 1540; finally, the PSI can enforce these provisions, acquiring a U.N. mandate as needed. These three proposals are not mutually exclusive, since the PSI can always act independently as a last resort, but they would ideally operate complementarily.

\section{International Maritime Organization}

The London-based IMO, established in 1948 to promote maritime safety, has adopted about forty conventions and protocols since its inception. ${ }^{93}$ At a December 2002 Conference on Maritime Security, IMO members approved a number of amendments to the 1974 Safety at Sea

\footnotetext{
92 See Ruth Wedgwood, Self-Defense, Pirates, and Contraband, Wall St. J., May 29, 2003, at A22.

${ }^{93}$ PERSBO \& DAVIS, supra note 47 , at 70.
} 
Convention $^{94}$ (SOLAS), establishing a comprehensive new security regime for international shipping that entered into force in July $2004 .{ }^{95}$ The centerpiece of these changes is the International Ship and Port Security Code (ISPS Code), requiring all vessels and port facilities to develop security plans in order to reduce their vulnerability to terrorism. ${ }^{96}$ Initial reports indicate that by August 2004 nearly 90\% of the over 9,000 declared port facilities had approved security plans. ${ }^{97}$ The ISPS Code also requires a number of tracking, monitoring, and security alert systems that should be useful in WMD interdiction missions. ${ }^{98}$

Perhaps more relevant to a quarantine regime is the IMO's 1988 Convention for the Suppression of Unlawful Acts Against the Safety of Maritime Navigation ${ }^{99}$ (SUA). Originally drafted to ensure the extradition and prosecution of persons who attacked or attempted to seize ships at sea, the IMO's Legal Committee began reviewing the SUA Convention in the wake of September 11th to consider amendments that would broaden the range of covered offenses to include acts of terrorism and introduce provisions for boarding vessels suspected of being involved in terrorist activities. ${ }^{100}$ Specifically, the United States proposed including boarding

\footnotetext{
${ }^{94}$ International Convention for the Safety of Life at Sea, Nov. 1, 1974, 1184 U.N.T.S. 276 (entered into force May $25,1980)$.

95 Press Release, International Maritime Organization, IMO Adopts Comprehensive Maritime Security Measures (Dec. 17, 2002), at http://www.imo.org/Newsroom/mainframe.asp?topic_id=583\&doc_id=2689.

${ }^{96} I d$.

${ }^{97}$ Press Release, International Maritime Organization, Security Compliance Shows Continued Improvement (Aug. 6, 2004 ), at http://www.imo.org/Newsroom/mainframe.asp?topic_id=892\&doc_id=3760.

${ }^{98}$ PERSBO \& DAVIS, supra note 477 , at 71.

${ }^{99}$ Convention for the Suppression of Unlawful Acts Against the Safety of Maritime Navigation, Mar. 10, 1988, 1678 U.N.T.S. 222 (entered into force Mar. 1, 1992).

${ }^{100}$ PERSBO \& DAVIS, supra note 477 , at 72.
} 
provisions that would streamline the process of gaining consent from flag states to inspect their vessels, similar to those included in its agreements with Liberia, Panama and the Marshall Islands. ${ }^{101}$ At its October 2002 meeting, the Legal Committee also discussed seven proposed criminal offenses, two of which concerned the use of a ship to transport WMD. ${ }^{102}$

The Legal Committee's response to the American proposals has been mixed. At a meeting in April 2004, the Committee "[R]ecognized that the inclusion of boarding provisions implied a substantial inroad into the fundamental principles of freedom of navigation on the high seas and the exclusive jurisdiction of flag States over their vessels."103 The moment of truth regarding the proposed SUA revisions will come in October 2005, when the IMO holds a diplomatic conference to adopt the amendments. ${ }^{104}$ Ideally, there will be a clear pronouncement condemning the transport of WMD for any reason, complementing similar resolutions at the U.N. Security Council. The IMO should also take a firm stance against the abuse of flag state privileges, developing rules that hold flag states and shippers responsible if their cargo contains WMD. ${ }^{105}$ These provisions will then form the normative substructure for building a global quarantine regime.

\footnotetext{
${ }^{101}$ Mark T. Alper \& Charles A. Allen, The PSI: Taking Action Against WMD Proliferation, THE MonITOR, Spring 2004, at 5. See supra note 466.

${ }^{102}$ PERSBO \& DAVIS, supra note 477 , at 72.

103 Press Release, Legal Committee, International Maritime Organization (Apr. 19-23, 2004), at http://www.imo.org/Newsroom/mainframe.asp?topic_id=280\&doc_id=3352.

104 Press Release, International Maritime Organization, Amendments to Suppression of Unlawful Acts (SUA) Treaties Set for Adoption $\quad$ October $\quad 2005, \quad$ in http://www.imo.org/Newsroom/mainframe.asp?topic_id=848\&doc_id=4416.

${ }^{105}$ PERSBO \& DAVIS, supra note 477 , at 90.
} 


\section{U.N. Security Council}

In April 2004, the U.N. Security Council unanimously passed Resolution 1540, its strongest proclamation against the proliferation of WMD to date. ${ }^{106}$ Acting under Chapter VII of the U.N. Charter, Resolution 1540 mandates that "all States shall refrain from providing any form of support to non-State actors that attempt to develop, acquire, manufacture, possess, transport, transfer or use nuclear, chemical or biological weapons and their means of delivery." 107 It also requires all states to "adopt and enforce appropriate effective laws" to prevent assisting non-state actors and to "establish domestic controls to prevent the proliferation of [WMD]." ${ }^{108}$ A special committee of the Security Council is responsible for monitoring the resolution's implementation based on reports from member states, the first of which were due in October 2004. ${ }^{109}$ On the positive side, Resolution 1540 is a step forward because "it makes strong national controls and enforcement a requirement rather than an option." ${ }^{110}$ At the very least, it reaffirms the universal appreciation of the threat posed by WMD, and forces states to examine their own nonproliferation laws and practices. The United States should work together with its fellow members on the implementation committee to seriously examine the reports submitted and offer model legislation to states that fall short of compliance. ${ }^{111}$

\footnotetext{
${ }^{106}$ SC Res. 1540, UN Doc. S/RES/1540 (2004).

${ }^{107}$ Id., para 1.

${ }^{108} I d$., para 2, 3.

${ }^{109} I d$., para 4.

${ }^{110}$ Andrew Semmel, Remarks at Conference on Global Nonproliferation and Counterterrorism: United Nations Security Council Resolution 1540 (Oct. 12, 2004), at http://www.state.gov/t/np/rls/rm/37145.htm.

${ }^{111}$ See United NATIONS, A MORE SECURE WORLD, supra note 122, at 45.
} 
At the same time, Resolution 1540 only addresses part of the WMD threat and, despite its reporting requirements, lacks any meaningful provisions for enforcing its mandates. By far the most glaring limitation is the specific restriction of several portions of the document to non-state actors. It may be true that non-state actors represent the most serious WMD threat, but this restriction clashes with Resolution 1540's unqualified opening statement that proliferation constitutes a threat to international peace and security. ${ }^{112}$ Even if a WMD transfer takes place between states, it represents proliferation and is a threat to international security. Every sale, every shipment, leads to a greater supply of WMD materials and further opportunities for diversion onto the black-market. A follow-on resolution should thus expand the scope of Resolution 1540 to apply to all transfers of WMD, regardless of the status of the proliferation recipient. It should also explicitly declare that no transportation method of WMD materials will receive sovereign protection, being an affirmative danger to the security of all states.

Resolution 1540 is also very conservative in its enforcement procedures, merely calling upon all states, "in accordance with their national legal authorities and legislation and consistent with international law, to take cooperative action to prevent illicit trafficking in [WMD]."113 Given that current international law does not allow for any form of nonconsensual interdiction on the high seas, willing WMD traffickers can still flaunt nonproliferation norms, notwithstanding what their national legal authorities say on the books. As mentioned in Part II.A, it is always possible that the Security Council could authorize a one-time interdiction mission under Article 39. ${ }^{114}$ Without the institutional and legal framework to support such a claim, however, this seems

\footnotetext{
${ }^{112}$ SC Res. 1540, preamble.

${ }^{113}$ Id., para 10.

${ }^{114}$ See supra note 88.
} 
highly unlikely. Alternatively, the United States, perhaps with the assistance of its PSI partners, could take enforcement matters into its own hands, along the lines of NATO's military action in Kosovo in $1998 .^{115}$ The Kosovo operation may have been successful and thus received tacit assent, but it is far from a favorable precedent for strengthening the role of the Security Council in international affairs.

To ensure its continued relevance in nonproliferation matters, the Security Council should embrace Resolution 1540's implementation committee, institutionalizing it and seeking to integrate it with the growing PSI framework. As proposed by several observers, the Security Council could establish an "interdiction committee" empowered to decide cases on short notice. ${ }^{116}$ In effect, an interdiction committee could serve to expedite Article 39 claims. Since the intelligence supporting interdiction is often of an extremely sensitive and fleeting nature, such a committee would be ideally suited to serve the dual needs of secrecy and speed. Correspondingly, the United States and other PSI members would be more likely to take their claims to the United Nations if such an institution was in existence, particularly if it was supported by an extended Resolution 1540 and new reforms under the SUA Convention.

No matter what system interdiction takes place under, there will always be concerns over the quality of intelligence and the consequences of boardings that uncover nothing. China in particular has expressed great skepticism of the PSI partly because of the false alarm in the 1993 interdiction of the Chinese vessel Yinhe, which U.S. intelligence services suspected of carrying

\footnotetext{
115 See PERSBO \& DAVIS, supra note 477 , at 75-76.

${ }^{116}$ Id., at 91; Andrew Prosser, The Proliferation Security Initiative in Perspective (June 16, 2004) (unpublished manuscript), at http://www.cdi.org/pdfs/psi.pdf.
} 
chemical weapons precursors to Iran. ${ }^{117}$ Unfortunately, beyond pooling intelligence resources and establishing a reviewing body at the Security Council, there is no sure-fire way to avoid mistakes. One possible compromise, listed in the section of UNCLOS that deals with exceptions to the flag state exclusivity rule, is to compensate the boarded ship "for any loss or damage that may have been sustained" if suspicions prove unfounded. ${ }^{118}$ Such a policy essentially transforms a form of property rule protection for ships suspected of transporting WMD into a liability regime, with a basis for accountability both before and after the interdiction mission. ${ }^{119}$ Setting monetary compensation for a violation of sovereignty is surely not a simple task, but the alternative of never allowing searches regardless of the level of suspicion is untenable.

\section{Proliferation Security Initiative}

Neither the IMO nor the U.N. has independent enforcement mechanisms, so the ideal entity to serve this function, preferably in conjunction with a Security Council interdiction committee, is the PSI. An integrative approach would bestow much needed legitimacy on U.S.led actions and would also provide potentially essential multinational cooperation in tasks such as freezing assets of WMD traffickers and providing access to air space and foreign bases. ${ }^{120}$ Especially if the Security Council integrates the SUA Convention amendments into an expanded version of Resolution 1540, the PSI would enjoy new legal authorities to act upon as opposed to

\footnotetext{
117 See Ye Ru'an \& Zhao Qinghai, The PSI: Chinese Thinking and Concern, THE MonITOR, Spring 2004, at 24; Patrick E. Tyler, No Chemical Arms Aboard China Ship, N.Y. TIMES, Sept. 6, 1993, at 4.

${ }^{118}$ UNCLOS, supra note 400, art. 110(3); see also CHURCHILL \& LOWE, supra note 72, at 210.

${ }^{119}$ See Allen Buchanan \& Robert O. Keohane, The Preventive Use of Force: A Cosmopolitan Institutional Proposal, ETHICS \& INT'L AFF., Winter 2004, at 1.

${ }^{120}$ See Michael Byers, Preemptive Self-defense: Hegemony, Equality and Strategies of Legal Change, J. PoL. PHIL., June 2003, at 171, 174 .
} 
the current limitations imposed by UNCLOS. As mentioned in Part I.E, existing legal authorities based upon a system of consent are only a partial answer to WMD proliferation and may not reach the most likely abusers of the system. Although the PSI's gradual accumulation of bilateral boarding agreements may at some point form the basis for a universal right of interdiction based on customary law, this is unlikely for the foreseeable future. ${ }^{121}$ Thus, the United States must either attempt to assert a broader right of interdiction under the doctrine of self-defense, which it has thus far been reluctant to do, or it must seek authority through international institutions, as outlined in this section.

It may be that the United States has to "go it alone" in the event that the Security Council does not authorize an interdiction mission that U.S. leaders believe is vital to national security. Even the U.N. High-level Panel acknowledged that the Security Council "may well need to be prepared to be much more proactive on [threats to international peace and security,] taking more decisive action earlier, than it has been in the past." ${ }^{\prime 22}$ If the Security Council fails to act or is stymied by a stubborn dissenting veto, the United States will have to seek alternative authority. One option is to turn to regional organizations, perhaps built on the PSI framework, and invoke Article 52(1) of the U.N. Charter: "Nothing in the present Charter precludes the existence of regional arrangements or agencies for dealing with such matters relating to the maintenance of international peace and security as are appropriate for regional action . . .."123 During the Cuban Missile Crisis of 1962, for example, the United States legitimized its maritime quarantine based on the provisions of the Rio Treaty of the Organization of American States, which sanctioned

\footnotetext{
${ }^{121}$ See Byers, Policing the High Seas, supra note 41, at $532-540$.

${ }^{122}$ United NAtions, A MORE SECURE WORLD, supra note 122, at 64.

${ }^{123}$ U.N. CHARTER, supra note 51, art. 52(1).
} 
assistance to meet threats of aggression in the region. ${ }^{124}$ Although some legal scholars were deeply critical of this justification, ${ }^{125}$ a similar strategy could serve to impose an inspection zone in a troubled region, perhaps if intelligence indicated that North Korea was engaging in widespread sales of WMD materials. As Ruth Wedgwood wryly observed, "If a maritime quarantine against offensive weapons was legal enough for John Kennedy, some might say, it should be legal enough for Ari Fleischer.",126

If even regional cooperation is not forthcoming, the United States would either assert a revised conception of self-defense or ultimately rely on what Michael Byers termed "exceptional illegality," wherein a state simply chooses to violate the law rather than seek to modify it. ${ }^{127}$ Considering the politically sensitive nature of interdiction operations, and the need for international cooperation in such missions, it is crucial that the United States do everything it can to avoid this situation and maximize the possibility that action can be taken through the Security Council. ${ }^{128}$ A sensible starting point is to ensure that all interdiction decisions are based upon sound criteria. Numerous authors have put forward factors for consideration, ${ }^{129}$ but the Highlevel Panel has produced a list that is the most relevant in this context, including (1) the seriousness of the threat; (2) the legitimacy of the purpose behind using military force; (3)

\footnotetext{
${ }^{124}$ See Leonard C. Meeker, Defense Quarantine and the Law, 57 AM. J. INT'L L. 515, 516 (1963).

125 See C. John Colombos, The International Law of the SEA 470 (6th ed. 1967); ThOMAS M. Franck, ReCOURSE TO Force: StATE ACtion AgAinst ThreAts AND ARMED ATtACKS 107 (2002).

${ }^{126}$ Wedgwood, A Pirate is a Pirate, supra note 6, at A12.

${ }^{127}$ See Byers, Policing the High Seas, supra note 41, at 543.

${ }^{128}$ Gareth Evans, When is it Right to Fight?, SuRVIVAL, Autumn 2004, at 59, 78.

${ }^{129}$ See, e.g., Id., at 75; Mallison, supra note 83, at 358; Roberts, supra note 266, at 519-525; Terrence Taylor, The

End of Imminence? WASH. Q., Autumn 2004, at 57, 68.
} 
whether the action is a last resort; (4) whether the means are proportional to the threat; and (5) whether there is a reasonable chance of success. ${ }^{130}$

Given the immense danger posed by WMD, the relative lack of ulterior motives for interdiction, the inability to defend against WMD use, and the focused nature of interdiction missions, these criteria should not be as hostile to interdiction as they may first appear. They are specific enough, however, to be preferable to a cost-benefit framework that boils down all the variables to the question of whether a state believes that the expected harm of a potential attack has reached an unacceptable level. ${ }^{131}$ One appropriate sliding variable might be the nature of the WMD or precursor material, with nuclear weapons requiring a lesser degree of threat/imminence than chemical weapons or dual-use items. ${ }^{132}$ Overall, these criteria should serve as a guiding principle for any actor or institution deciding on interdiction, be it the United States, the PSI, or the Security Council interdiction committee.

\section{CONCLUSION}

\footnotetext{
${ }^{130}$ UnITED NATIONS, A MORE SECURE WORLD, supra note 122, at 67 (“(a) Seriousness of threat: Is the threatened harm to State or human security of a kind, and sufficiently clear and serious, to justify prima facie the use of military force? (b) Proper purpose: Is it clear that the primary purpose of the proposed military action is to halt or avert the threat in question, whatever other purposes may be involved? (c) Last resort: Has every non-military option for meeting the threat in question been explored, with reasonable grounds for believing that other measures will not succeed? (d) Proportional means: Are the scale, duration and intensity of the proposed military action the minimum necessary to meet the threat in question? (e) Balance of consequences: Is there a reasonable chance of the military action being successful in meeting the threat in question, with the consequences of action not likely to be worse than the consequences on inaction?").

${ }^{131}$ See Yoo, supra note 26, at 757.

${ }^{132}$ See PERKOVICH, supra note 9, at 38-39.
} 
Even before FDR applied the term to international affairs, states used quarantines to protect themselves from threats on the high seas, requiring the temporary detention of incoming ships and sailors to ensure that they did not pass on the plague or other infectious diseases. Today, since a local system of quarantine is impractical with the flood of international trade and travel, the quarantine must take on a global character, aiming to prevent the spread of WMD altogether. This article began by showing why a new framework is needed, analyzing how export controls, deterrence, defenses, or even more active disarmament measures will not easily contain the WMD threat. Part II.A then examined the legal principles behind a global quarantine, demonstrating that Article 51 of the U.N. Charter rests upon an evolving notion of self-defense that may need to adapt in order to respond to catastrophic but non-imminent threats. Finally, this article explored the various international institutions available to serve as a framework for a global quarantine, concluding that the IMO can articulate principles which the Security Council can extend and universalize, relying on the PSI for enforcement.

As I acknowledge in Part II.B, this article does not claim to identify the sole path for achieving a global quarantine. Its main purpose is to demonstrate the urgency and sound legal basis for a quarantine, as well as offer some initial ideas for how to begin making it a reality. Some observers may contend that my proposals go too far and there is only a modest chance that they will gain widespread approval. It may be that IMO members will refuse to make reforms to the SUA Convention, and that Resolution 1540 represents the furthest the Security Council is willing to go in countering proliferation. As Part II.B.3 reflects, though, in that event the default situation is ever-increasing reliance on the PSI, since the threat posed by WMD will not go away and cannot be ignored. The prospect of a more robust role for the PSI, given the prominent position of the United States within it, may be disconcerting to much of the world. Many people 
are fearful of granting the United States any greater latitude in confronting proliferation and terrorism than it already possesses, especially in light of its failure to find any WMD in Iraq. However, as explained in Part II.A, the best way to maintain the relevance of international institutions like the Security Council is to frame them so that the United States and others have an incentive to use them. If the U.N. cannot expedite interdiction claims through a special committee, there is little chance at all that PSI nations will turn to it for authorization.

Other critics may object that these proposals do not go far enough. As mentioned in Part I.E, since interdiction relies heavily on intelligence capabilities and good fortune, some might conclude that forcible disarmament is the only reliable solution. Especially if a series of WMD terrorists attacks were to occur, I fear that victimized states would believe they had no other choice but to eliminate all WMD supplies beyond their allies. Given the incredible risk and likely damage from such a course, as outlined in Part I.D, I believe a global quarantine offers a middle ground approach with the best matching of ends and means. To avoid leaving interdiction to the United States alone, and to forestall more drastic disarmament measures, the world community should join together to draw a clear line in the sand, on the water, and in the air forbidding all forms of WMD transfer. 